\title{
PATIENT AND PHARMACIST INTERACTIONS IN SELF MEDICATION IN MAKASSAR
}

\author{
Asyhari Asyikin ${ }^{1}$, A. Agustang ${ }^{2}$, Yamin Sani ${ }^{3}$, Sulaeman Samad ${ }^{4}$ \\ E-mails: asyhari_asyikin@yahoo.com, andiagust63@gmail.com, \\ meimell8076@gmail.com, essamad2011@gmail.com \\ ${ }^{1}$ Candidate Doctor in Sociology State University of Makassar, \\ ${ }^{2}$ Professor of Sociology State University of Makassar, \\ ${ }^{3}$ Professor of Sociology Hasanuddin University, \\ ${ }^{4}$ Doctor of Sociology State University of Makassar (INDONESIA)
}

DOI: $10.7813 / 2075-4124.2014 / 6-2 / B .8$

Received: 16 Oct, 2013

Accepted: 25 Feb, 2014

\begin{abstract}
Self-medication is a conscious effort to heal itself through the purchase of medicines needs directly to the pharmacy. Self medication is a form of health behavior essentially a person's reaction to stimuli with illness and disease, health care system, and the environment. As one of health supplier services, pharmacists play big roles and responsibilities to self medication. These roles and responsibilities are based on pharmaceutical care philosophy. The objective of this research is to reveal the interaction relationship between actors in social process that cause self medication action to happen in Makassar. This research is a qualitative research, using 6 informants as data source which is collected using deep observation and interview. The result of this research shows that communication between actors in self medication does not go smoothly, which is seen from many drug misuse cases within Makassar society. From the observation of the informants, it was found a case of long term misuses of deksamethason and cyproheptadine to raise appetite, prednisone dan phenylbutazone to cure rheumatic as well as CTM, prednisone, and aminophylline to heal asthma disease in long term. The drug misuse continues to be repeated due to the absence of public information available about the drugs they use, especially to the side effects of these drugs when they are repeatedly used continuously in the long run. The implication of these drug misuses can cause degenerative diseases along with a bunch of consequences. Based on this fact, it can be concluded that the interaction between actors (patient-pharmacist) in self medication action within Makassar society does not run well.
\end{abstract}

Key words: Self medication, interaction, Makassar Society

\section{INTRODUCTION}

Self medication is one of the society efforts to keep their health. According to World Health Organization data ${ }^{[1]}$, in many countries, up to $80 \%$ people who get sick try to take self medication by themselves. While the data in Indonesia show that around $60 \%$ people take self medication using modern drugs as first action when they get sick ${ }^{[2]}$

Some factors such as social economy, easy access on drug products, disease and rehabilitation management, demography and epidemiology, reformation of health sectors and the availability of new easy-touse products take parts in increasing self medication act ${ }^{[1,3]}$.

Pharmacists play important roles and big responsibilities on self medication. This pharmacist role and responsibility based on pharmaceutical care philosophy. Based on this philosophy, pharmacist responsibilities are to identify, solve, and prevent drug-related problems from happening, so optimum therapy results can be achieved. More specifically, pharmacist responsibilities to self medication act of the society have been formulated by The International Pharmaceutical Federation (FIP) and The World Self Medication Industry (WSMI) in one collective agreement. The agreement claims that pharmacist responsibilities to self medication are to give suggestion and to accompany patients in choosing proper drug, to provide information about side effects that might occur in pharmacy industries, to suggest reconciliation to the doctor, and to tell the right way to store drug [4]. Whereas, according to $\mathrm{WHO}$, the pharmacist functions and responsibilities to self medication are that of communicator, quality drug supplier, trainer and supervisor, collaborator, and health promoter ${ }^{[1]}$.

The result of initial observation at some pharmacies in Makassar shows that pharmacists haven't done their job properly yet. In pharmacies, the consumers (patients) usually just give the recipe, pay, and take the drugs. Even when the patients take the drugs, there is almost no information given by the employees of the 
pharmacies regarding the drugs. Not to mention, the consumers never know whether or not there is any pharmacist working at the pharmacy at that time.

The spread of drugs without recipe these past few days enable individuals to solve their medical problems faster, more economical and comfortable without visiting a doctor. Whereas the use of drugs without recipe and proper information may cause the use of irrational drug that end up in cost increase and more serious diseases of the patients even though the drugs actually have label indicating prohibitions or certain limitations regarding the drugs.

In Indonesia, the implementation of drugs information services is the obligation of pharmacists' community which is arranged in Health Ministry Regulation number: 919/MENKES/PER/X/1993 ${ }^{[5]}$, in which this service must be based on the society need. By implementing this obligation, the community of pharmacists has received Legal Protection along with some other benefits such as building patients trust to the community of pharmacists' personnel and the increase of income both in moral and material aspects. More importantly, the patients can get benefits such as the use of rational drug, efficient cost and education about health.

Self medication has both advantages and disadvantages. One of self medication advantages is that the drugs needed are already available in the drug case ${ }^{[6]}$. Another advantage is that self medication is cheaper, fast, and easy and does burden the implementation of health system and can be done by the patients themselves, which saves one's budget and doctor's fee, immediately get back to work ${ }^{[7]}$. However, self medication also has disadvantages such as drugs misuse, harmful side effects occurrence and metabolism change due to long term use of certain drugs. In this case, the drugs which are used might trigger degenerative diseases such as hypertension, diabetes, and renal.

This research is conducted because in most cases self medication in Makassar tends to increase, even though there is no definite numbers that proves the fact because substantively self medication is done individually. However, the indication of the case increase can be predicted through one of the selling and distributing drugs result data from three pharmacies which are the objects of this research. The amount of free drug sale income result in the last three years continues to increase, which is identified to has been caused by many important factors, such as: (1) society knowledge about serious and light diseases and medical need, (2) availability and easier access of the need of drugs which are sold freely and commercially in many drugstores and pharmacies and (3) traditional/alternative medication as part of national health system have become more and more expanded and acceptable. Social implication of self medication increase in Makassar can be seen that the society tend to have cheaper medication.

Based on previous various explanation, it is can that self medication has become an alternative taken by the society to increase medical availability to cure diseases. The later problem is that self medication can become the cause of medication error. The Case which is observed in this research is the long term misuse of certain drugs

The objective of this research is to reveal interaction relationship between actors in social process that causes self medication act to happen in Makassar. Social change interaction in this case is reciprocity communication between actors in self medication act between individual actors with pharmacist personnel in pharmacies.

\section{RESEARCH METHODS}

This research was categorized as a qualitative research, which was conducted on long term drug misuse cases (more than 6 months). The cases that were observed included: (1) the desire to boost body weight using cyproheptadine and deksamethason, (2) the cure of rheumatic using phenylbutazone and prednisone, (3) the cure of asthma using three variants drugs which are CTM, aminophylline, and prednisone. Data collecting was done using deep observation and interview on 6 patients of self medication actors in Makassar who used the drug as informants. Then conducted focus group discussions with pharmacists who are practitioners and academics. This research was conducted on September 2013.

\section{RESULTS AND DISCUSSION}

In this research, it was found that there were six drugs misuse cases through self medication. Self medication using drugs irrationally was found within mid to low level economy society. This research observation result showed that the drugs which they used caused side effects which were fatal when used in long term. Interview results from six informants showed that they used the drugs upon the information from their friends and closest family based on proves from other people who succeeded in using the drugs. This act is upon social exchange theory which was claimed by Homans that surroundings have big influences on someone's behavior ${ }^{[8]}$.

Self medication which was stated in this research is a continuous act or behavior which was caused by the interaction between the societies as health seekers with the pharmacists did not go smoothly in purchasing the drugs. Less effective and communicative interactions between actors caused the society to take the next self medication using deksamethason and cyproheptadine to fatten the body, especially the misuse of certain drugs which were forbidden to be taken without doctor's recipe, or at least were appropriate with the function and use of drug that they consumed.

Less effective interaction relationship between actors in self medication can be seen clearly from the lack of knowledge of the society about the term "self medication". Research interview result showed that the purchase of drugs by society was just an effort to cure diseases practically. Wrong self medication found in the society was caused by the easy of obtaining the drugs freely from the pharmacies. 
Negative self medication case was quite easily found in the use of drugs category ciproheptadine and deksamethason to fatten the body, which obtained from the following information: that informants bought deksamethason and cyproheptadine to raise fatten the body based on information from friends as mutual traders at the market, and by witnessing the direct prove of the effects on that friend.

Based on the information above, it could be known that the informants consumed various drugs category ciproheptadine and deksamethason without sufficient knowledge of these drugs use. Another informant said that he used the drug because after consuming the drug, the body became fat, his sleep got more comfortable.

The continuous drug misuses became worse because pharmacists did not give education, in this case, information to the consumers about the effects of the drugs as well as the goal of medication in proper ways so that the society as consumers would just use the drugs properly which would be suitable with the benefits they felt. Less appetite and sleep became the reasons why the two variants of the drugs were consumed. After consuming the drugs, the raise of body weight and fat and also good quality sleep encouraged them to continue consuming the drugs. Self medication act truly could be harmful because it did not properly follow the rules of drugs use.

Basically, humans need many things in building social relationship including expressing purposes, goals, and hopes to get response (reaction) from another. Feedback relationship (action-reaction) in sociology is called social interaction. This is implied if someone (consumer) need drugs information from pharmacist at a pharmacy and a pharmacist is expected to give positive responses by providing optimum drugs information services. Therefore, direct communication that shows social interaction between them will happen ${ }^{[9]}$.

Another drug misuse happened in rheumatic cure. Information from informant made us know that they used phenylbutazone and prednisone according to cure rheumatic because their friends also consumed the drugs. And after consuming the drug, their rheumatic relapsed. Therefore they consumed the drugs continuously to prevent relapses.

The same goes for the cure of asthma which was done by the society through self medication using three various drugs, namely CTM, aminophylline, and prednisone. The informants we met said they had been using the drugs to cure asthma disease for 2 years continuously. The reason to use the drug was because the same drugs were given by a nurse at a place they diagnosed their health. Because of the effective effects and it was easy to get drug in pharmacy, they were encouraged to take self medication. Another reason which was said by the informants was related to additional cost when they had consultation with health staff that they were left with no choice but to buy drugs freely in pharmacy.

The easy of getting drugs also backed self medication act, which was supported by the increase numbers of pharmacies and drug stores in Indonesia. Seeing the development from 2007 to 2009, the growing numbers of pharmacies compared to the numbers of distribution channels increased relatively stable in which one pharmacy will serve \pm 17.800 people ${ }^{[10]}$. A phenomenon which was seen in Makassar also showed increase numbers of pharmacies and drug stores as well as new development occurred in drug purchase service through pharmacies. Now pharmacies do not only serve to deliver drugs to houses, but also they are open on 24 hours, up to accepting orders by phone (delivery service). The easy ways like these had contribution in self medication.

All the information explained above and according to focus group discussion result, it can be understood that interaction relationship between self medication actors with pharmacists or pharmacist staffs must be built well, in this case pharmacist staffs were expected to be initiative in giving information about drugs. In this case, Pharmacist staffs were those who understood how to drugs were consumed well by the society especially about doses, side effects, the ways to use, contra indication and possible effect of long term use. Therefore, the diseases that would not start to recover and self medication is continued, it is recommended to see a doctor.

According to self medication cases above, it was shown that interaction tendency between actors in self medication did not go smoothly. On pharmacy side, drugs purchase by consumers was not followed by the efforts to give drugs information service. Whereas on the society side as consumers, the purchase of various drugs which type and category were not suitable for their main healing the functions was especially just based on the information from their surroundings or on effects experience and benefits obtained by people in their surroundings. Especially when they did not feel any harmful side effects during the use of the drugs because they had never had a check up on their health. This also made them continuously took self medication act in the society.

Therefore, any specific efforts and real actions from pharmacies in socializing the information about drugs use drugs to consumer society were needed so that the drugs would not turn to be harmful to body health either periodically or permanently. Therefore, continuous drugs information service functions needed to be optimized ${ }^{[11]}$.

The research result above showed that the interactions were the main components of social process in the field of society health. Interaction in this case was feedback communication between individuals (self medication actors) with pharmacist personnel (pharmacists) to achieve health recovery goals. This can be seen from the unavailability of maximum drug information services by pharmacists so that irrational drugs use would happen which would bring social problems to the society. According to Handayani and friends research (2006), the unavailability of information given by pharmacists was caused by a gap indication between the readiness of pharmacists to give drug information and the need of pharmacies consumer information ${ }^{[12]}$.

The actors in the structure were concrete people in continuous actions and events happened in the world, while the structure was defined as institution (pharmacy) and human resource (staffs) which was formed by and formed repetitive social practice. It could be seen from the observation result in research location that interaction relationship between patients as actors and pharmacists at pharmacies as organization did not run. The activity was just focused on transactional pay and buy without communication on drug information service. 
Duality plot of the agent-structure lied on social structure which was the outcome and also the structure fact as guide in conducting social practices in any location and time as action result. The nature of the structure was to control timeless and spaceless and also virtual, so that they could be adapted on any situation and condition ${ }^{[13]}$.

Another finding in this research related to self medication act in negative way which was done by people in Makassar was the lack of government control in drugs distribution channels. On the other side, organization, corporation, institution which most focused on drugs distribution control which was consumed by the society in order to fulfill the need of health service which could not function in maximum due to classic reasons. Fund allocation to operate the work plans of work institute which was not equal to become one among many reasons of poor effort in supervising efforts as well as drug distribution control which would be used by the society.

Having so-so income, the society tried to get cheap drugs and to get drug needed easily in self medication. The interrelationship between consumers and pharmacists could be seen from easy access to buy drug that they needed. This gave contribution to pharmacists to do drugs commercialization without considering safety of drugs use on the patients. The unavailability of real government control to drugs distribution caused the drug commercialization more uncontrolled. The impact of the activity could be harmful to society especially because of the repetitive drugs use which was irrational.

Data and fact showed that the distribution of light and heavy category of drugs transactional could be found at any pharmacies in Makassar. It was that monthly report on up to date drugs condition tended to be watched in black and white, without further actions such as physical examination of the drugs which was still available in pharmacies. This condition then triggered the efforts which were made possible for the pharmacy owners to continue drugs distribution to the government freely, without any worrying about the main goals of the health labors units they managed which was the establishment of good society health from time to time.

The relation data and fact which was found in the research above was relevant enough to focus group discussion result with some pharmacy managers and also with medical staffs (pharmacists, pharmacist staffs, and also doctors). The information obtained was that one important matter which needed to get serious attention from the government to prevent negative self medication act in the society was to intensify the monitoring of work plans institutionally according to health law mechanism which had been arranged clearly.

Social interaction was defined as dynamic social relationship. The social relation can be the relation between one individual and another individual, between one group another group, also between groups and individuals. There were also symbols which means were given to anyone who used them

Social interaction is dynamic relation, which involved the relation between individual and individual, between individual and group, or between group and group in term of cooperation, competition, or conflict ${ }^{[12]}$.

\section{CONCLUSION}

Patient and pharmacist interactions in self medication in Makassar did not go smoothly, which caused self medication act through drug misuse continued to take place. This meant that social communication between society as consumers or patients that used drugs was not facilitated well enough by pharmacists when transactional activities took place at pharmacies. This miscommunication was actually based on two processes namely (a) associative process was the existence of society compromise attitude which allowed the inability of family social and economy as base act to do self medication, and (b) dissociative process was the imbalance of some associative process which led the society be unable to fulfill the need of health service which was supposed to improve the society health quality.

\section{REFERENCES}

1. WHO, 1998. The Role of the Pharmacist in Self-Care and Self-Medication. The Hague, The Netherlands: WHO, p.1-11.

2. Departemen Kesehatan RI, 1995. Tentang Pelayanan Kefarmasian, Jakarta : Direktorat Jendral Pelayanan Kefarmasian dan Alat Kesehatan Departemen Kesehatan RI.

3. PAHO, 2004. Drug Classification: Prescription and OTC Drugs. PAHO, p.1-2.

4. FIP, 1999. Joint Statement By The International Pharmaceutical Federation and The World SelfMedication Industry: Responsible Self-Medication.

5. Depkes, 1993, Permenkes No. 919/Menkes/Per/X/1993 Tentang Kriteria Obat yang Dapat Diserahkan Tanpa Resep, Jakarta

6. Tjay dan Raharja, 2010, Obat-Obat Sederhana untuk Gangguan Sehari-Hari, Cara-cara menangani sendiri gangguan sehari-hari dengan terutama obat-obat bebas terbatas (self-care), Gramedia, Jakarta.

7. Anief, 2000, Apa yang Perlu Diketahui Tentang Obat. Jogjakarta: Universitas Gajah Mada.

8. Homans, George C., 1974, Social Behavior: Its Elementary Forms, rev. edition, New York; Harcourt, Brace, Javanovich.

9. Effendy, Uchjana Onong. 1995. Ilmu Komunikasi Teori dan Praktek. Bandung: Remaja Rosdakarya.

10. Kartajaya, H., dkk., 2011, Self Medication, Who is Benefits and How is at Loss, MarkPlus Consulting,

11. Suryawati, S., 1997. Menuju Swamedikasi Yang Rasional. Jogjakarta: Pusat Studi Farmakologi Klinik dan Kebijakan Obat Universitas Gadjah Mada. 
12. Handayani, dkk, 2006, Eksplorasi Pelayanan Informasi yang dibutuhkan Konsumen Apotek Dan Kesiapan Apoteker Memberi Informasi Terutama Untuk Penyakit Kronik Dan Degeneratif, Majalah Ilmu Kefarmasian, Vol. III, No.1, April 2006, 38-46.

13. Giddens, Anthony, Daniel Bell, Michael Forse, etc. 2004. Sosiologi; Sejarah dan Berbagai Pemikirannya. Interpreter; Ninik Rochani Syam, Native title; La Sociologie Histoire et Idees. Yogyakarta: Kreasi Wacana. 
Copyright of International Journal of Academic Research is the property of International Journal of Academic Research and its content may not be copied or emailed to multiple sites or posted to a listserv without the copyright holder's express written permission. However, users may print, download, or email articles for individual use. 